\title{
A Medico-Geographical Study in the Seasonal Variation of Morbidity and Mortality by Disease
}

\author{
by \\ Masako Momiyama (Sakamoto) \\ Meteorological Research Institute, Tokyo \\ (Received June 22, 1965)
}

\begin{abstract}
Relations between human diseases, particularly their incidence and seasonal changes, have long been studied by a number of scholars. It has recently been found that the variation of morbidity and mortality by disease is dependent upon socio-economic conditions as well as upon natural environments, meteorological and geographical, whereas the seasonal cycle has so far been reflected more or less in the distribution of various ailments. Take, for instance, dysentery, which formerly raged in the hot months. It now shows a very small hill in summer, and its morbidity in winter has been increasing year after year in proportion to the gradual decrease in summer.

The seasonal variation of mortality by disease has also undergone marked changes. And these changes can be classified into two types: transitory and reversing.

The transitory-type change is seen in cancer, which took the biggest toll in August in the first decades of the current century, but the mortality peak of which has moved from summer to autumn, October in particular. The coefficient of seasonal variation has shrunk from about 0.1 to 0.04 , or nearly one half.

The reversing-type change may further be divided into two subtypes, $A$ and B. In subtype A the summer peak of mortality has caved off into a valley, while on the other hand the winter level, because of its minor decline, has been closed up as a new summit. Falling under this category are gastritis-enteritis group avitaminosis (beri-beri) and tuberculosis. In the case of Subtype B, there were formerly two peaks, one in summer and the other in winter, but now the summit remains intact only in the cold season, whereas it has completely disappeared in the hot season. Diseases registering such seasonal variation of incidence are apoplexy, heart disease and senility.

What are the factors responsible for such seasonal changes in mortality? As for the infirmities of age, high mortality in summer may be considered as having come from the bad influence of the hot season upon old patients and the lack of medical services for them in former times. The recent development of medicine and pharmacology, however, has come to enable old cases to survive the effects of summer heat, but they cannot endure winter cold. This also may be mentioned as one
\end{abstract}


of the factors. As another cause may be mentioned the recent contraction of seasonal variation in major physical functions of the human body, such as basal metabolism and blood specific gravity of red corpuscles.

The retardation of mortality claims closer attention. After the Second World War, mortality markedly declined for many diseases, but it has come to mark time of late. Signs of such retardation can be seen in every season for pneumonia, enteritis, tuberculosis and other germ diseases. On the other hand, incidence has been on the steady increase, particularly in winter, for apoplexy, heart disease and other senile maladies, probably because old people have been increasing relatively in the population structure.

Diseases showing marked seasonal variation in morbidity and mortality have long been called "seasonal diseases". But this is not an exact definition, gividg an impression that seasonal changes are reflected, as they stand, in the occurrence and incidence of diseases. In fact, many of the so-called seasonal diseases have proved not seasonal in nature.

The author has been studying the seasonal variation of mortality by disease. This has really been unavoidable because statistical data are available only for deaths and are lacking for morbidity. In point of fact, however, it is more important for us to identify all the conditions, pathological processes and results of various diseases, if we are to clarify the over-all seasonal rhythm of human ailments, and to work out adequate action, medical or social, against the ever-higher mortality concentration in winter.

But studies in this direction have just been started, and this paper is intended not to present the author's findings but to list up the new problems she now is anxious to analyze, looking forward to frank comments and thoughtful suggestions.

\section{Relations between morbidity and mortality - seasonal rhythm of diseases}

The first issue is the influence of seasonal changes upon the morbidity of diseases. Then, it is essential to clarify all the pathological processes and conditions from morbidity to mortality.

The period of pathological process from contraction, through discovery by diagnosis, to death is relatively short for some diseases, but for others it is very long. Such a difference in pathology makes it highly difficult for us to analyze the seasonal variation of mortality as well as morbidity. In fact, pathological data are lacking, and the analysis of mortality variation based on vital statistics soon comes to its limits. In order to make up for the incompleteness of statistical analysis, it is necessary for us to investigate into clinical and pathological case studies and thereby to derive, if possible, coordinated conclusions.

Fortunately enough, data are available in Japan for morbidity as well as mortality for two diseases, i.e. dysentery and tuberculosis.

Dysentery:-As may be noted in the seasonal disease calendar prepared by the 
author, dysentery is the only disease raging in summer, but its toll has dropped to the minimum. (Fig. 1). Both morbidity and mortality have changed markedly in recent years.

Tokyo - to $(1906 \sim 1910)$



Tokyo-to $(1957 \sim 1961)$

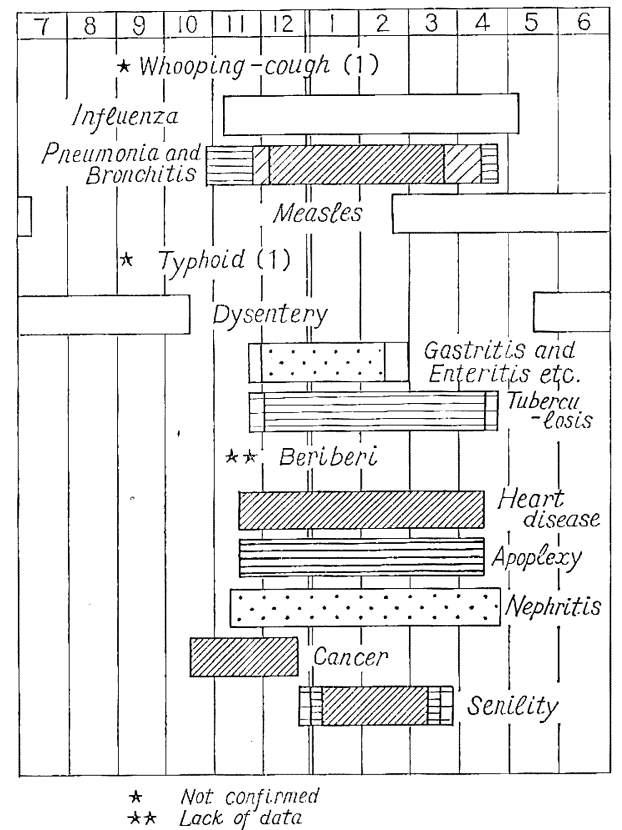

Fig. 1. Calendar of seasonal disease (Tokyo-to).

A comparison of morbidity and mortality shows an interesting picture. During 1957--61, morbidity was considerably higher than mortality, but both registered their peaks in summer. It is also to be noted that the summer peak of the morbidity index was much lower during 1957-61 than that during 1952--56, and that the vari-

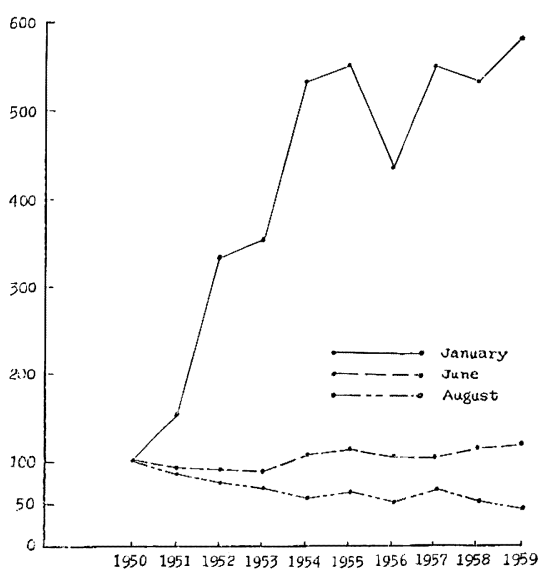

Fig. 2. Monthly Dysentery Patient by Year (Index of Percentage). ation coefficient of the mortality index tapered off by about one half from 0.375 to 0.583 in the meantime.

Morbidity curves classified by year show that the peak in August, 1950, caved off steeply in 1959, whereas the morbidity index in January (1950 as 100) rose up year after year and reached 600 in 1959. (Fig. 2). It is also interesting to note that almost no change has been witnessed in June and August (even a slight decline seen in the latter month). The steady gain of morbidity in winter, contrasted with the retardation in summer, claims serious study.

All this may be, in the author's opinion, ascribed to the following: i.e. 1) the ever-wider home treatment of this disease by antibiotics, 
which results in incomplete curing, the increase of germ carriers and the subsequent propagation of dysentery germs, 2) the inapplicability of prevention by vaccine unlike the case of typhoid, 3) the recent increase of drug-resistant bacteria, and 4) the more efficient heating of housing, particularly the kitchen, than ever, which probably facilitates the propagation of bacteria in the cold season. It is also to be noted that dysentery reportedly prevails in winter in the United Kingdom and Canada (the morbidity peak seen in March in Canada).

Tuberculosis:-As for this chronic ailment, morbidity suddenly curves up in June and remains at the peak up to September. On the other hand, mortality is extremely low on the whole and drops to the bottom in summer. (Fig. 3).

Generally speaking, the contraction of tuberculosis is more frequent in winter than in the hot months. But three or four months usually pass away before cases are discovered by Roentgen ray test. It is little wonder, therefore, that morbidity shows a sudden pickup around June. Moreover, it is said that cases

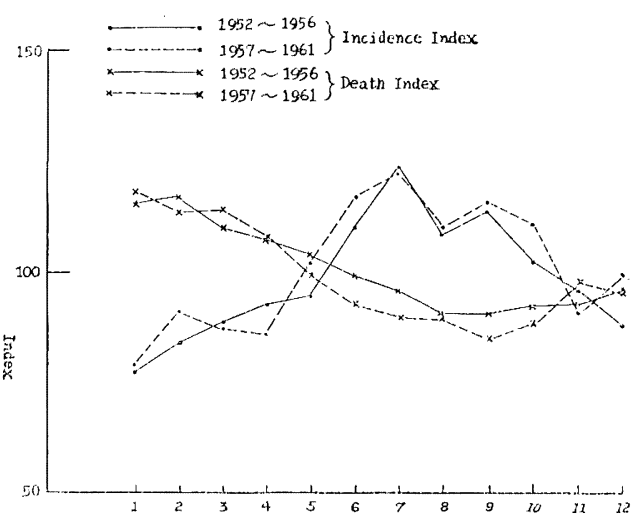

Fig. 3. Tuberculosis (Japan). often turn out so serious that they can seldom be cured by drugs. They are liable to die in the long run, especially if they take cold or suffer from pneumonia. This may account for the high mortality in the cold season.

It is worth mentioning that mortality as well as morbidity formerly showed the highest mark from early summer to autumn. In the past decade or so, however, the peak has come to turn up in winter as will be explained later.

\section{Types of seasonal rhythm of diseases}

A chronological study reveals that there are several types of seasonal variation in mortality. As for some diseases, the highest toll has moved from summer to winter or autumn. In other cases, there were two peaks, one in summer and the other in winter, but the peak now appears only in the cold months. For the sake of convenience, such seasonal changes are classified into two types: transitory and reversing. The latter is further divided into two subtypes, $\mathrm{A}$ and $\mathrm{B}$.

Reversing type:-In the case of subtype A, the summer peak has disappeared completely or caved off into a valley, while on the other hand the winter level, due to its slight decline in recent years, has been closed up as the highest summit. Falling under this category are gastritis-enteritis group and avitaminosis, which took the extremely high toll in summer in the first decades of this century. (Fig. 4a.) In the meantime, the coefficient of seasonal variation has decreased by nearly one half from over 0.4. Tuberculosis also belongs to this type, but its seasonal variation has been much smaller. 


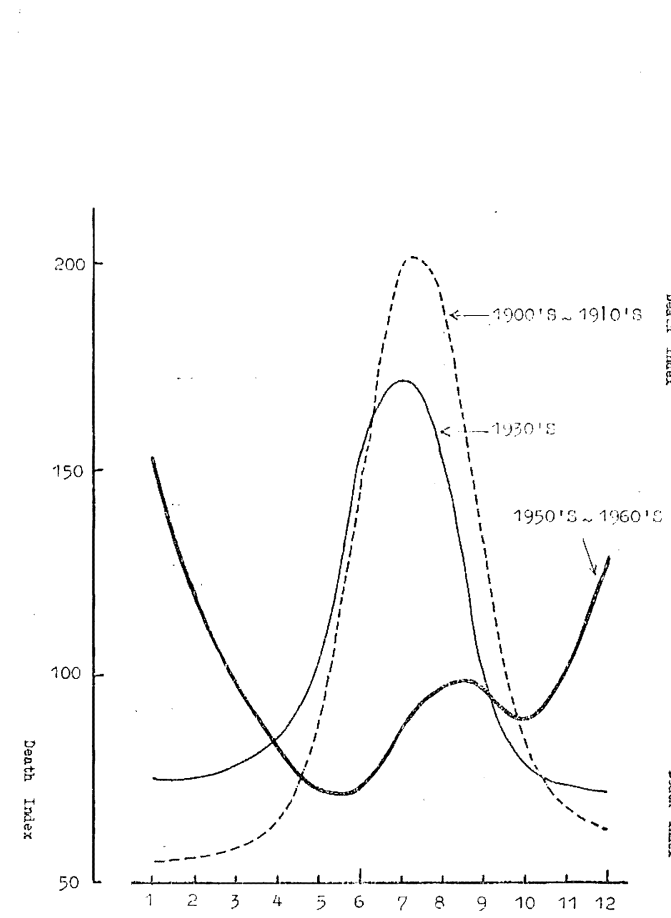

(a) Gastritis and Enteritis groups (Reversing type "A")

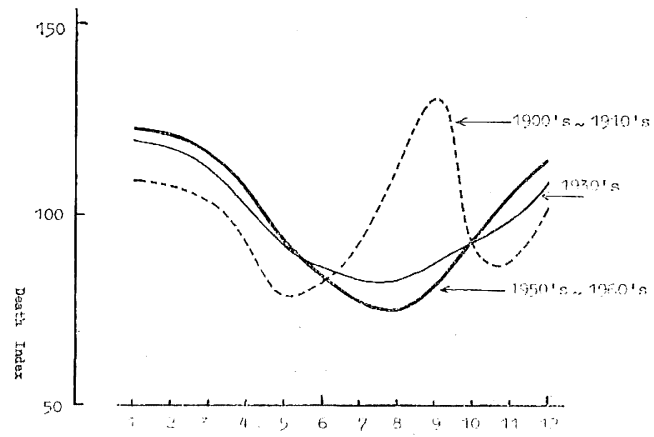

(b) Apoplexy (Reversing type "B")

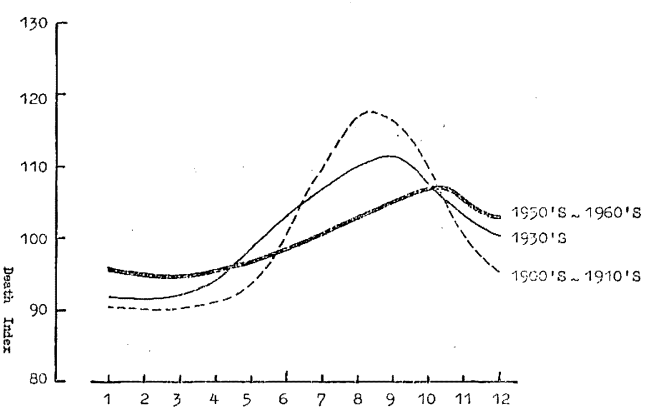

(c) Cancer (Transitory type)

Fig. 4. Seasonal variation model of mortality.

Diseases of subtype B are senile infirmities, such as apoplexy, heart disease and senility. In this case, there were formerly two peaks (the summer peak higher in some localities), but the summer peak has gradually gone off and disappeared completely, while on the other hand there now remains a peak only in winter. (Fig. 4b.) As for apoplexy, the variation coefficient was as high as 0.22 during 1900-20 but fell to 0.11 in 1930's. But it has again risen to 0.15 or so in recent years due to the recent levelling-up of the winter peak.

Transitory type:-There is only one disease, or cancer, registering the seasonal change of this type. (Fig. 4c.) In the first decades of this century, the mortality peak was witnessed in August, but it moved to September in 1930's and to October in recent years. It may be expected to make another migration to the cold months. The variation coefficient has dropped from 0.1 to 0.04 , a marked shrinkage of more than $50 \%$.

A look at the mortality indices classified by season, however, indicates that pathologies are rather delicate and complex for cancer, though there can be no denying the transition of the mortality peak from summer to autumn. The gap between the summer and winter indices is getting so close that the above-mentioned reversion from summer to winter may take place sometime in the future. (Fig. 5) Quite independent from this tendency, be it noted, the autumn index has been higher than the annual average, just as in the case of the summer index, and it has re- 
cently become more prominent in contrast to the levelling-off of the summer and winter indices. And the actual change will turn out much more complicated than the statistics seem to show.



Fig. 5. Annual variation and Seasonal variation of death rate (Cancer).

Furthermore, physiological functions of the human body appear to vary rhythmically along with the changes of the season. For instance, basal metabolism shows some sort of seasonal variation. According to Professor Korehiro Ogata, of Kumamoto University, the annual average from 1947 through 1952 was relatively low throughout the whole year and there was a big difference between the minimum and the maximum. During 1953-58, however, the average level proved somewhat higher and the difference got much closer. (Fig. 6a.) The seasonal variation coefficient was 0.585 in

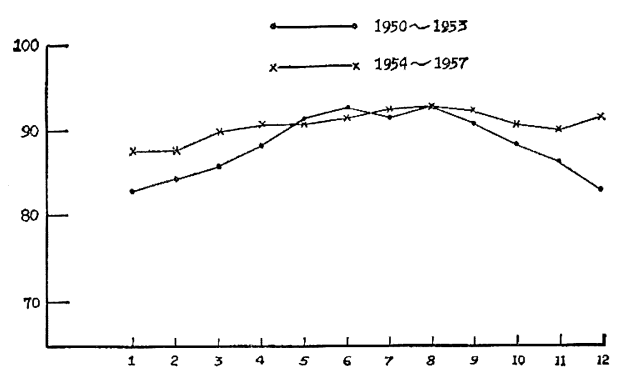

Fig. 6b. Seasonal Variation of Blood Specific Gravity.

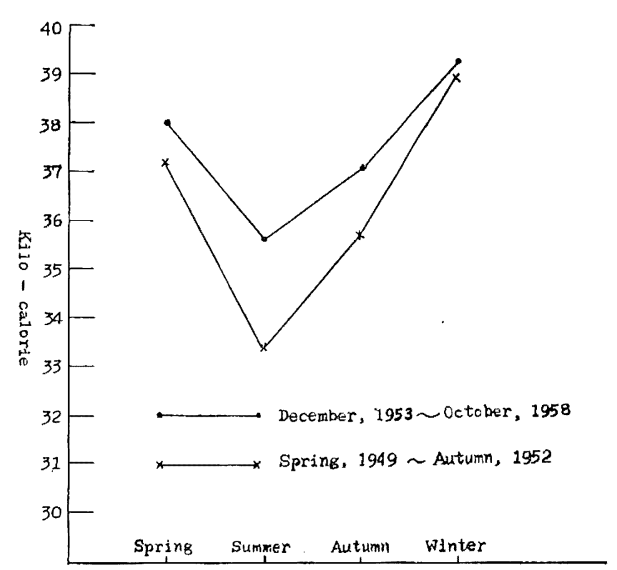

Fig. 6a. Seasonal Variation of Basal Metabolism.

the former and came 0.333 in the latter period, bespeaking the gradual contraction of seasonal rhythm.

Another function varying seasonally is the specific gravity of red corpuscles. A report (made public by the Medical Faculty of Tokyo University) indicates that the seasonal variation curve of the specific 
gravity of red corpuscles showed a slow peak in summer during 1950-53 but levelled off on a straight line during 1954-57. (Fig. 6b.) The variation coefficient, therefore, decreased from 0.037 to 0.016 in the meanwhile.

These two examples indicate the steady shrinkage of seasonal rhythm in physiological functions. But we have not reliable and convincing data enough to enable us to derive conclusions. More examples and cases must be collected in the future in order to identify not only morbidity and mortality but physiological functions as well.

\section{Factors for Recent Changes in Seasonal Rhythm of Diseases}

Let us investigate into the factors considered responsible for the recent changes in the seasonal rhythm of diseases, particularly in mortality.

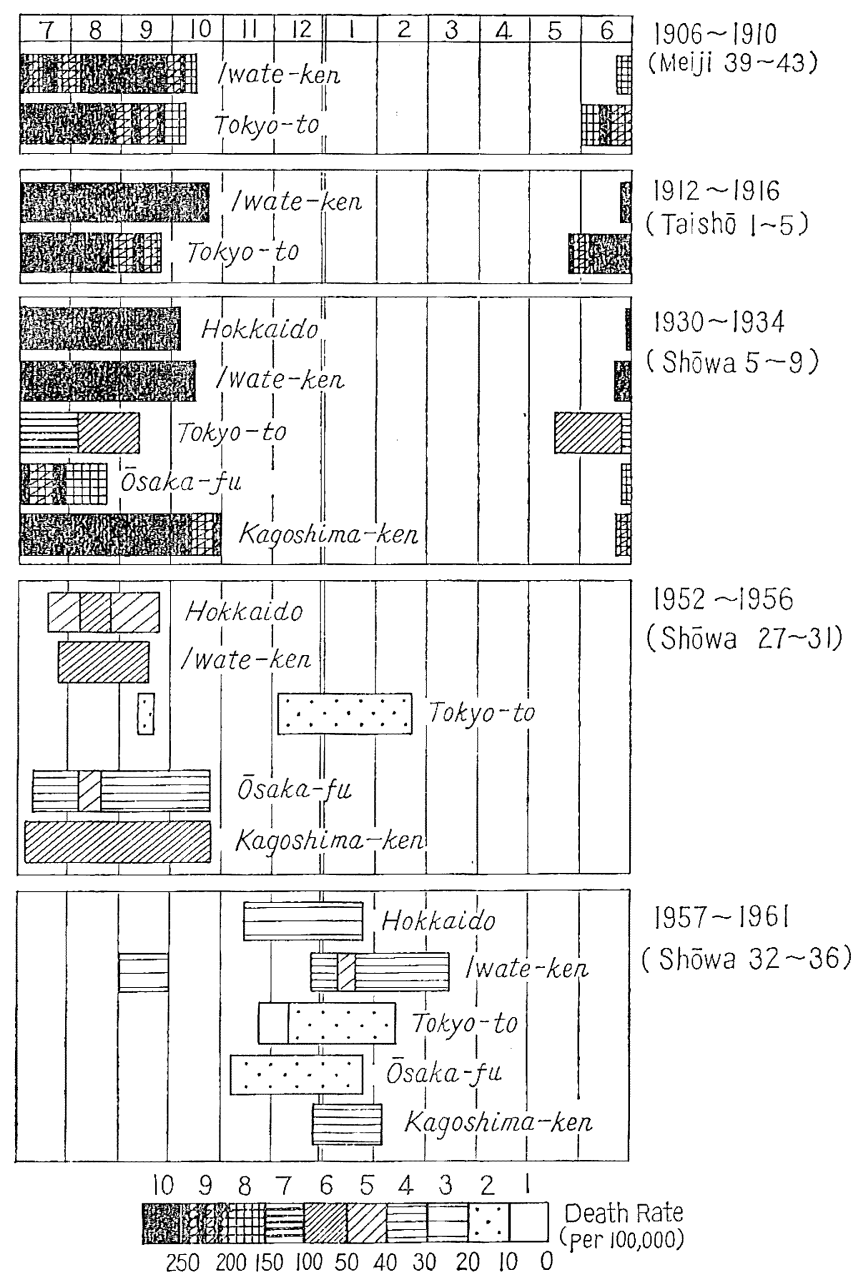

Fig. 7. Calendar of Gastritis and Enteritis etc. 


\subsection{Reversing Type}

Gastritis-enteritis group:-This disease group of digestive organs raged, taking an extremely big toll, in the hot months from 1900 through 1930, particularly in local prefectures (Iwate, Hokkaido and Kagoshima) as may be noted in Fig. 7. Since 1960's, however, not only the mortality rate has declined markedly but also the season of prevalence has moved to the cold months. It is also to be noted that the reversion of the mortality peak from summer to winter took place much earlier in urban areas (Tokyo and Osaka) than in rural districts, and that a small peak still remains intact in less advanced prefectures in Japan (e.g. Iwate).

Most responsible for such rapid decrease of mortality and the reversion of the peak is none other than the ever wider use of effective antibiotics. Other factors are the postwar improvement in public health and daily provisions control services, the levelling-off of the living standard, and the propagation of household electric appliances (refrigerators in particular).

Classified by age group, mortality has proved much higher for infants (under four years old) and old people (over 70 years). It is also interesting to note that infants show the mortality peak only in winter, where old people have two peaks, one in winter and the other in summer. (Fig. 8).

Mortality is very low for the other age groups (10-40 years old) and slightly picks up in September alone. This means that the high mortality in winter, as far as gastritis-enteritis group is concerned, comes from the frequent deaths in this season of infantile and senile groups.

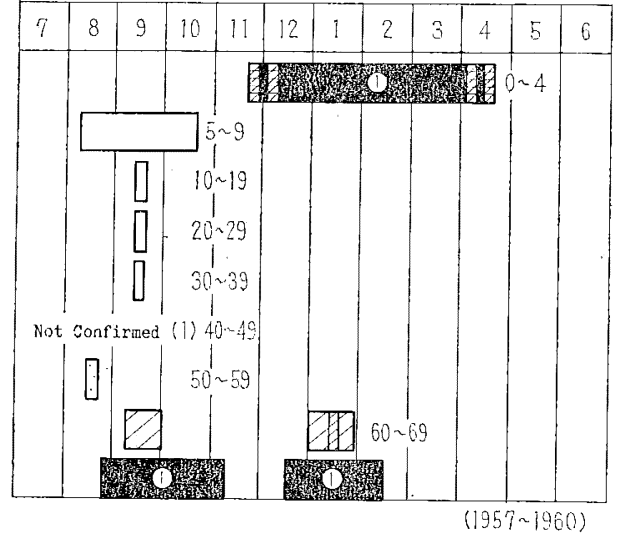

Fig. 8. Calendar of Gastritis and Enteritis Group.

Tuberculosis:-The seasonal variation curves of this malady in the past six decades have been traced back. It is found that the mortality peak appeared from July through September, from 1899 up to sometime in 1940's (Fig. 9), and that signs of notable change came to the fore after the war's end. Around 1947, mortality curved up, though not steeply, from April through June, suddenly turning downward about 1952, while the winter level was gradually closed up as a summit. In recent years (1957-61), the mortality curve has completely reversed itself, compared with that in the first decades of this century.

The seasonal variation coefficient of tuberculosis mortality is shown in Table 1. It was of course very big in the first decades of this century and markedly declined in 1920's. Due to the mortality concentration in winter, however, it has again curved up notably in recent years.

It is not easy to account for these changes in the seasonal variation of tuberculosis. The high mortality in summer in the first decades of this century may be interpreted as follows: Digestive tuberculosis prevailed in the hot months, taking 
an extremely big toll for a long period in these years. The successful development of chemotherapeutics after 1952 caused the caving-off of the summer summit, finally ushering in a reversion of high mortality from summer to winter. At present, deaths from tuberculosis are more frequent among older people than in the younger generation. It is also to be noted that digestive tuberculosis is now very rare, in contrast to the relative increase of the respiratory one which seldom causes deaths. After all, the ever wider use of antibiotics has greatly contributed to the considerable reduction and seasonal reversion of mortality.

Fig. 3 compares the mortality as well as the morbidity curves for 1952-56 and 1957-61. During the latter period, morbidity was considerably high in summer, and mortality very low, though its peak appeared in winter.

Classified by age group, mortality in recent years stand at 150-200 (per 100,000) for old people (older than 70 years), to be compared with 100-150 for people in the 60 's and 50-100 for those in the 30's, 40's and 50's. And deaths are most frequent in winter for older people.

\subsection{Reversion type B}

Apoplexy:-Seasonal variation curves by year are chronologically shown for this disease in Fig. 10. In the first years of the current century, there were two mortality peaks, and the summer summit which usually appeared in September (August and October in some years) was higher than the winter one. In 1920's, the peak remained in September, but the variation coefficient dropped by one half to 0.11. Then the summer peak got lower year after year, and the variation curve completely reversed itself in 1947, curving up in winter and caving off in summer. On the other hand, however, the variation coefficient resumed an upward trend.

Heart Disease :-A chronological change in mortality is traced back to 1899 as shown in Fig. 11. In the first decades of the current century, deaths were most frequent in the hot months (August and September in particular), but their peak was not so high as the curve of apoplexy. From 1920's to 1930's, the curve was rather erratic: peaks appeared in winter and autumn, or only one peak got prominent in the cold season, and so on. After the war, the curve got stabilized, showing only one summit in winter just as in the case of apoplexy.

How, then, can the relative lowering of the mortality peak in summer be interpreted? It is rather difficult to give a definite answer, but the following somewhat bold in nature, is offered as the most plausible one.

Formerly, old people used to die of senile diseases from summer through autumn due to the evil influence of summer heat upon their bodily stamina as well as conditions. Thanks to the recent progress of medical techniques and services and the successful dosage of new drugs, however, they have come to survice summer heat somehow or other, but they often die in the cold season. Generally speaking, big doses of vitamin compounds, Ringer's solution, glucose, etc. can revitalize many cases and prolong their lives. Thus, those who otherwise might die in summer would often survice up to fall or winter. In former times, sufferers from digestive ailments (gastritis-enteritis group, dysentery, typhoid, etc.) were often told to abstain from 


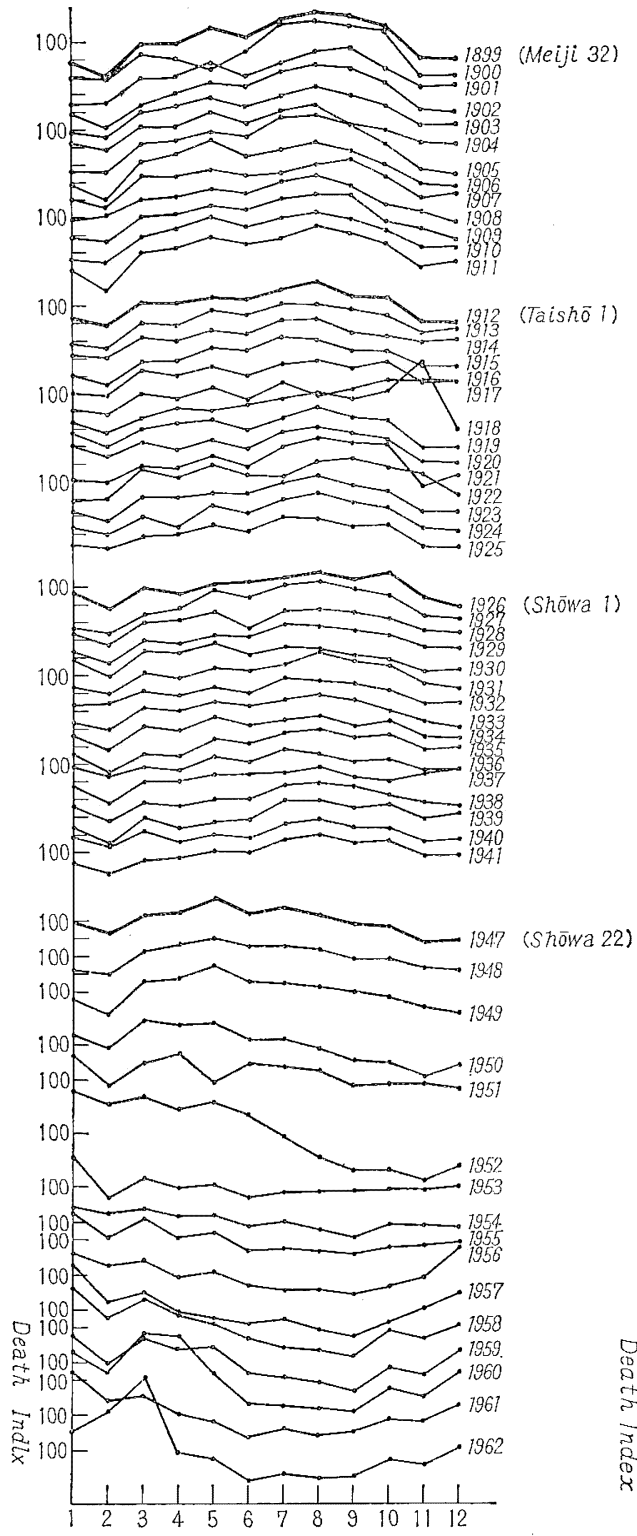

(a) Japan

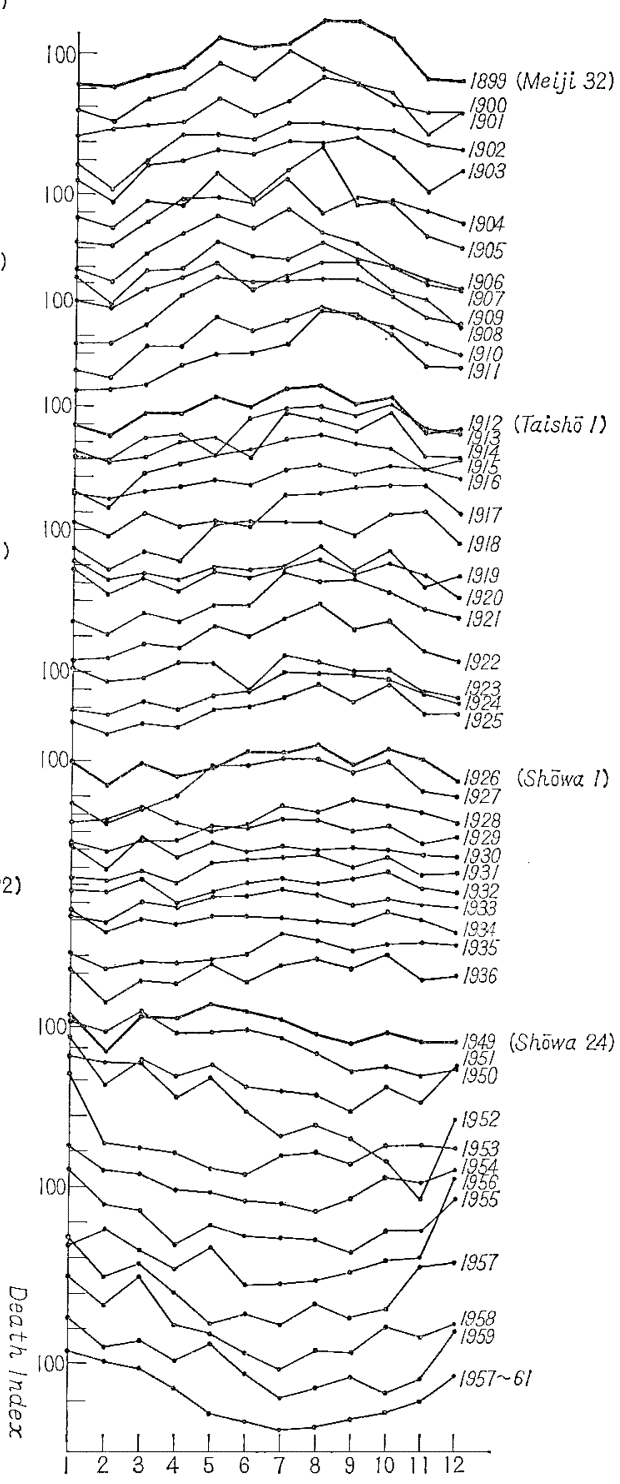

(b) Tokyo

Fig. 9. The Death Index Curves of Tuberculosis by Year 


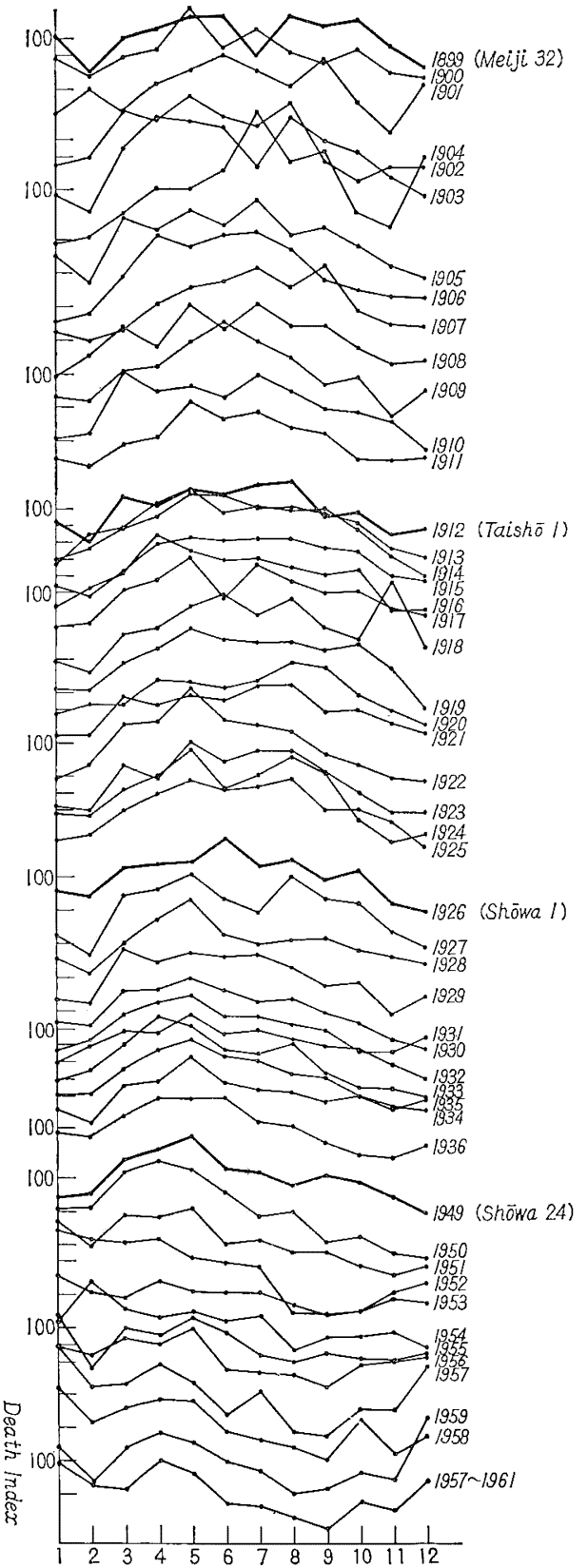

Table 1. Variation Coefficient of Seasonal Disease

\begin{tabular}{|c|c|c|c|c|}
\hline & & Apoplexy & $\begin{array}{c}\text { Heart } \\
\text { Disease }\end{array}$ & $\begin{array}{l}\text { Tubercu- } \\
\text { losis }\end{array}$ \\
\hline \multirow[t]{3}{*}{ (Meiji 32) } & 1899 & 0.125 & 0.124 & 0.114 \\
\hline & 1900 & 0.044 & 0.090 & 0.088 \\
\hline & 1901 & 0.139 & 0.080 & 0.117 \\
\hline \multirow[t]{5}{*}{35} & 1902 & 0.095 & 0.086 & 0.097 \\
\hline & 1903 & 0.097 & 0.092 & 0.089 \\
\hline & 1904 & 0.165 & 0.075 & 0.078 \\
\hline & 1905 & 0.086 & 0.071 & 0.115 \\
\hline & 1906 & 0.110 & 0.070 & 0.099 \\
\hline \multirow{5}{*}{40} & 1907 & 0.216 & 0.108 & 0.088 \\
\hline & 1908 & 0.113 & 0.134 & 0.089 \\
\hline & 1909 & 0.138 & 0.085 & 0.085 \\
\hline & 1910 & 0.082 & 0.057 & 0.092 \\
\hline & 1911 & 0.108 & 0.090 & 0.094 \\
\hline \multirow[t]{4}{*}{ (Taishō 1) } & 1912 & 0.111 & 0.075 & 0.081 \\
\hline & 1913 & 0.113 & 0.081 & 0.077 \\
\hline & 1914 & 0.104 & 0.086 & 0.083 \\
\hline & 1915 & 0.115 & 0.073 & 0.077 \\
\hline \multirow[t]{5}{*}{5} & 1916 & 0.112 & 0.116 & 0.064 \\
\hline & 1917 & 0.128 & 0.106 & 0.065 \\
\hline & 1918 & 0.130 & 0.211 & 0.070 \\
\hline & 1919 & 0.136 & 0.075 & 0.071 \\
\hline & 1920 & 0.126 & 0.104 & 0.067 \\
\hline \multirow{5}{*}{10} & 1921 & 0.114 & 0.102 & 0.073 \\
\hline & 1922 & 0.125 & 0.110 & 0.088 \\
\hline & 1923 & 0.103 & 0.075 & 0.079 \\
\hline & 1924 & 0.133 & 0.082 & 0.073 \\
\hline & 1925 & 0.118 & 0.156 & 0.063 \\
\hline \multirow{4}{*}{ (Shōwa 1) } & 1926 & 0.093 & 0.082 & 0.067 \\
\hline & 1927 & 0.092 & 0.084 & 0.104 \\
\hline & 1928 & 0.103 & 0.110 & 0.051 \\
\hline & 1929 & 0.107 & 0.103 & 0.073 \\
\hline \multirow[t]{5}{*}{5} & 1930 & 0.102 & 0.093 & 0.075 \\
\hline & 1931 & 0.102 & 0.130 & 0.055 \\
\hline & 1932 & 0.091 & 0.105 & 0.051 \\
\hline & 1933 & 0.113 & 0.129 & 0.061 \\
\hline & 1934 & 0.114 & 0.164 & 0.054 \\
\hline \multirow[t]{5}{*}{10} & 1935 & 0.088 & 0.127 & 0.061 \\
\hline & 1936 & 0.139 & 0.196 & 0.042 \\
\hline & 1937 & 0.101 & 0.125 & 0.053 \\
\hline & 1938 & 0.110 & 0.158 & 0.057 \\
\hline & 1939 & 0.111 & 0.161 & 0.068 \\
\hline \multirow[t]{2}{*}{15} & 1940 & 0.140 & 0.180 & 0.041 \\
\hline & 1941 & 0.096 & 0.156 & 0.056 \\
\hline \multirow{3}{*}{ (Shōwa 22) } & 1947 & 0.204 & 0.137 & 0.071 \\
\hline & $\begin{array}{l}1948 \\
1948\end{array}$ & 0.154 & 0.118 & 0.097 \\
\hline & 1949 & 0.119 & 0.119 & 0.073 \\
\hline \multirow[t]{5}{*}{25} & 1950 & 0.153 & 0.200 & 0. 099 \\
\hline & 1951 & 0.157 & 0.192 & 0.075 \\
\hline & 1952 & 0.141 & 0.177 & 0.178 \\
\hline & 1953 & 0.151 & 0.244 & 0.058 \\
\hline & 1954 & 0.123 & 0.157 & 0.061 \\
\hline \multirow[t]{5}{*}{30} & 1955 & 0.146 & 0.171 & 0.068 \\
\hline & 1956 & 0.160 & 0.211 & 0.084 \\
\hline & 1957 & 0.156 & 0.238 & 0.106 \\
\hline & 1958 & 0.148 & 0.199 & 0.114 \\
\hline & 1959 & 0.159 & 0.198 & 0.096 \\
\hline \multirow[t]{3}{*}{35} & 1960 & 0.168 & 0.248 & 0.148 \\
\hline & 1961 & 0.173 & 0.247 & 0.102 \\
\hline & 1962 & 0.185 & 0.252 & 0.162 \\
\hline
\end{tabular}




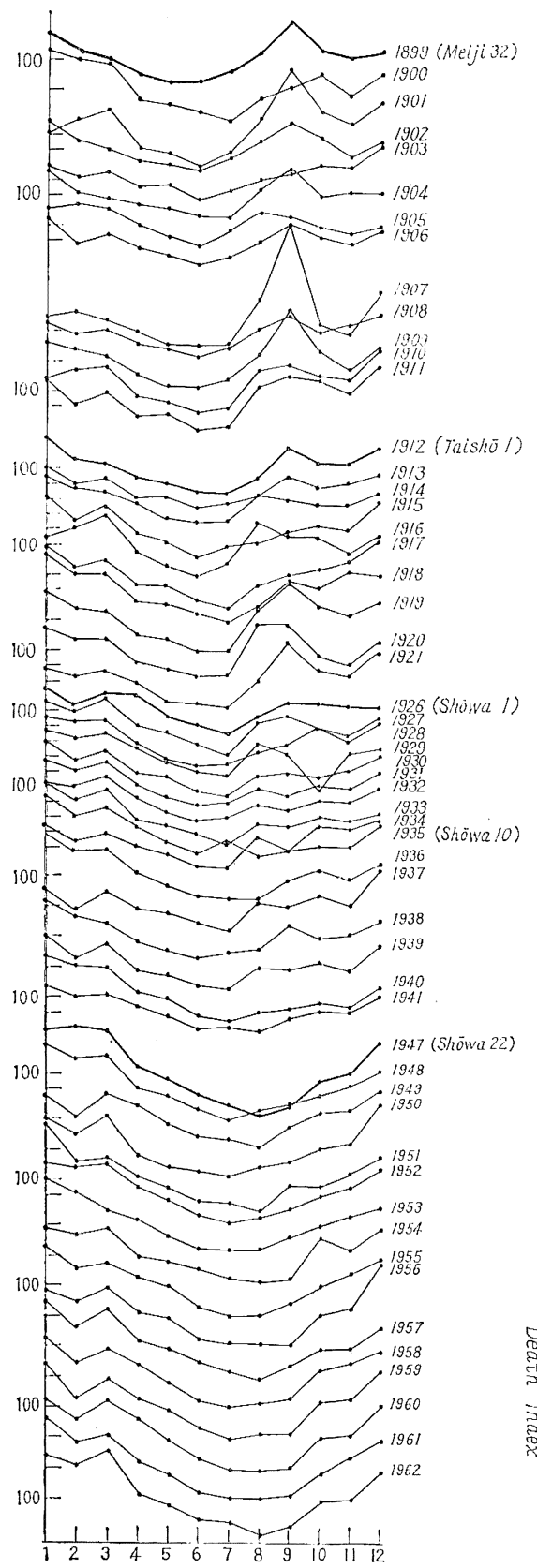

(a) Japan

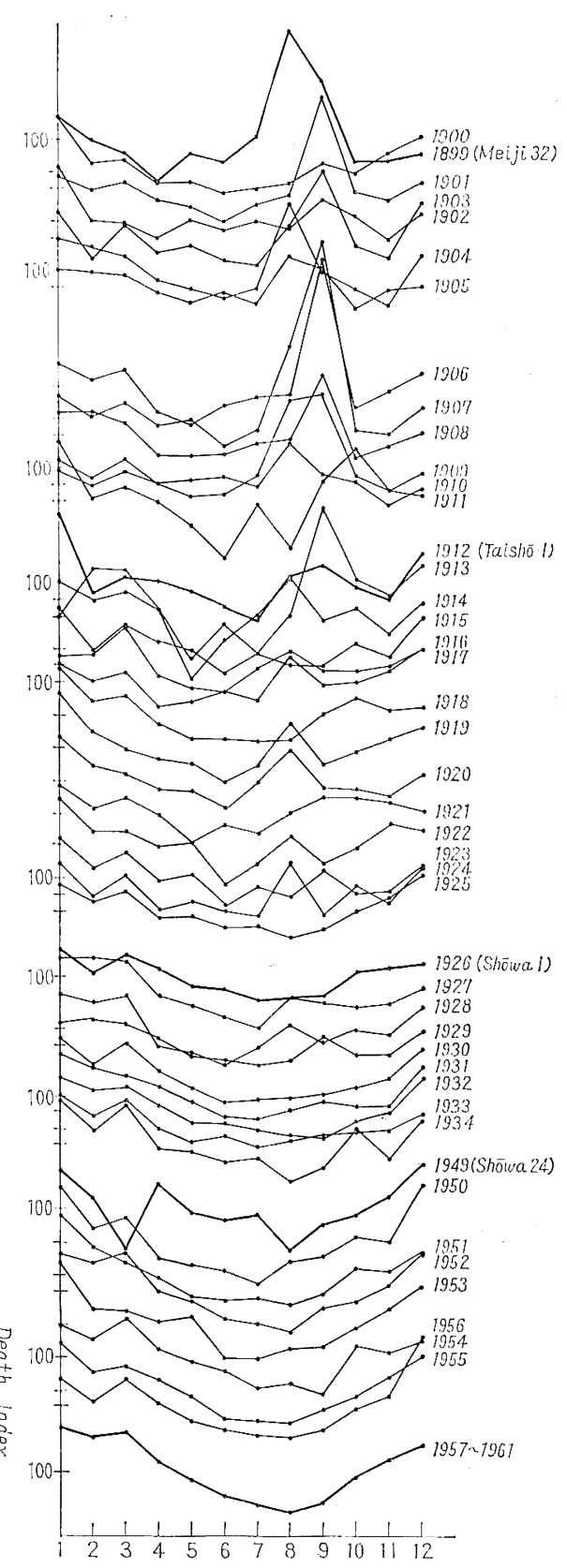

(b) Tokyo

Fig. 10. The Death Index Curves of Apoplexy by Year. 


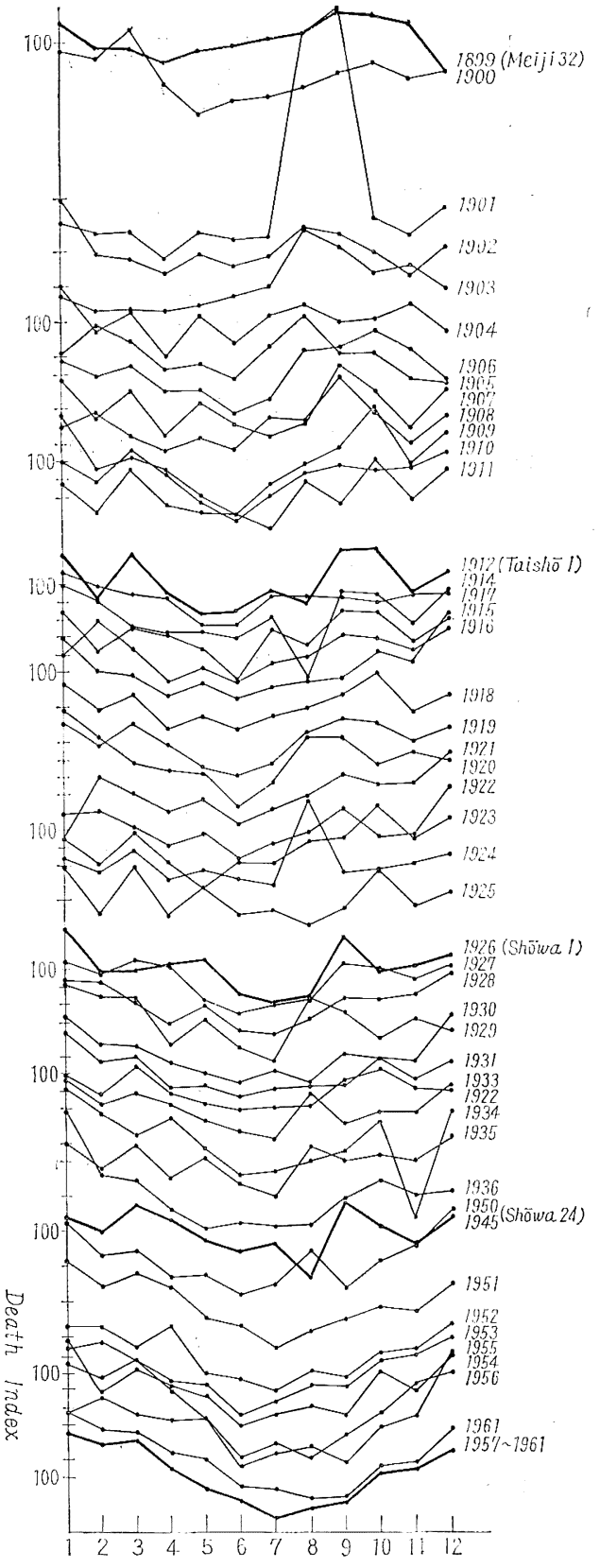

(c) Osaka

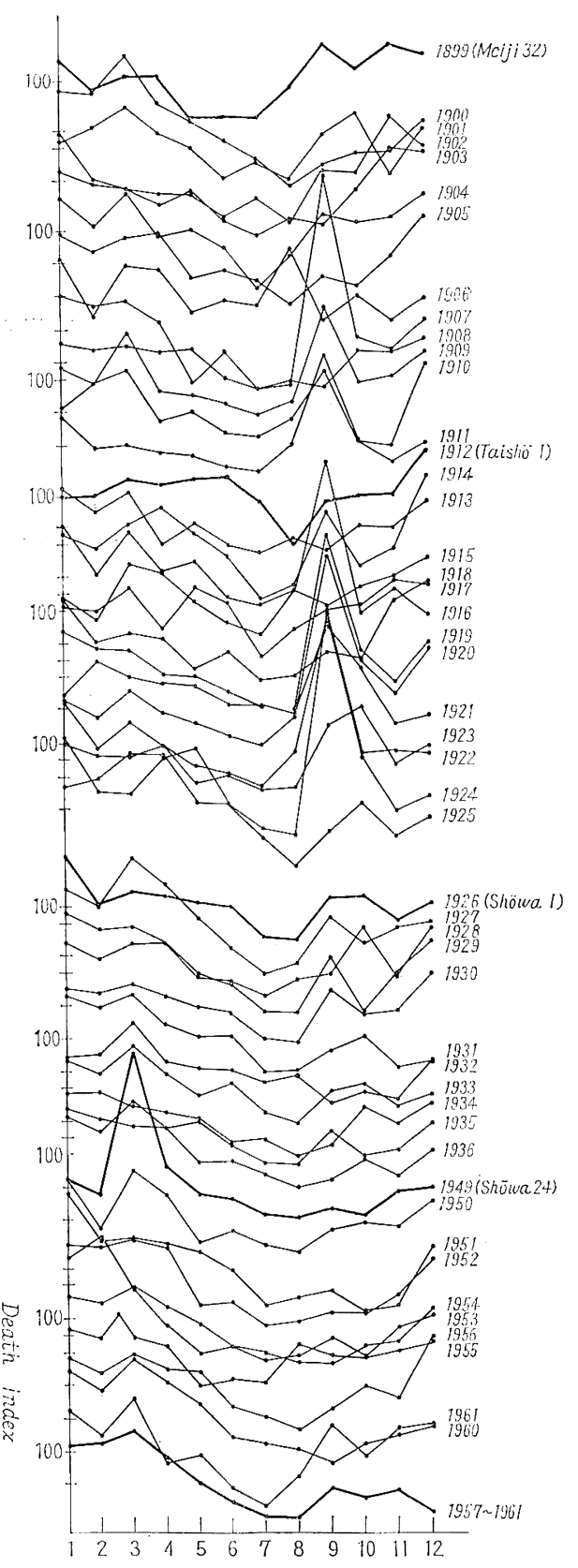

(d) Iwate 


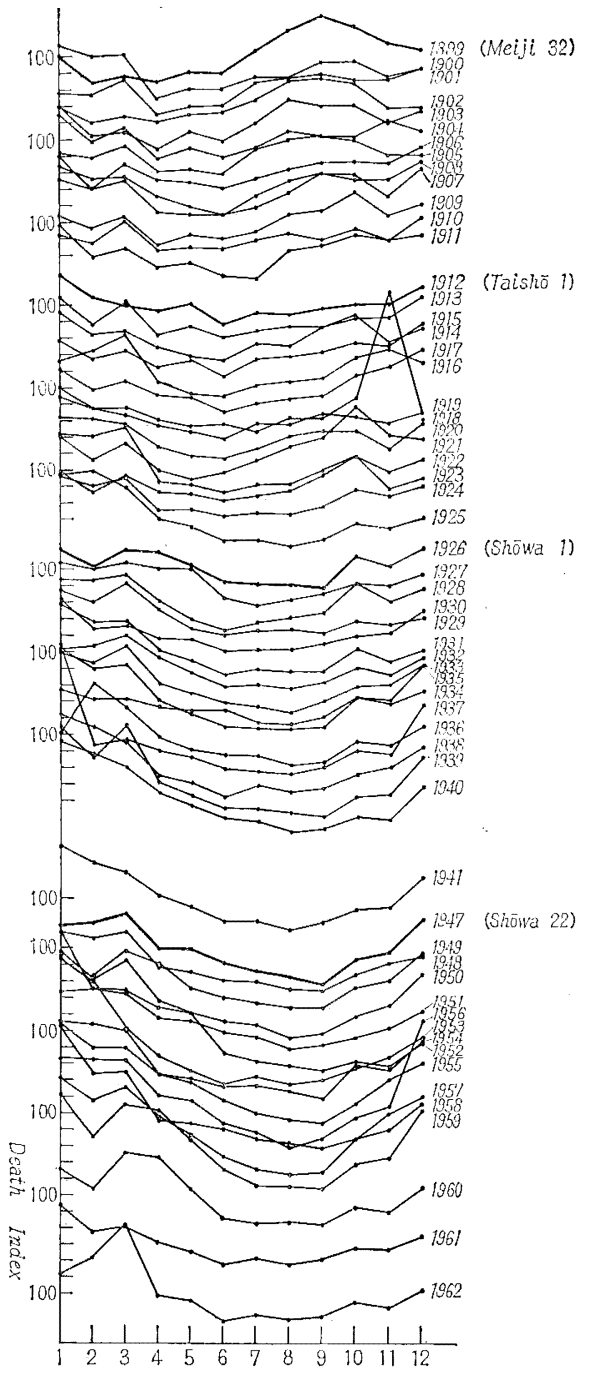

(a) Japan

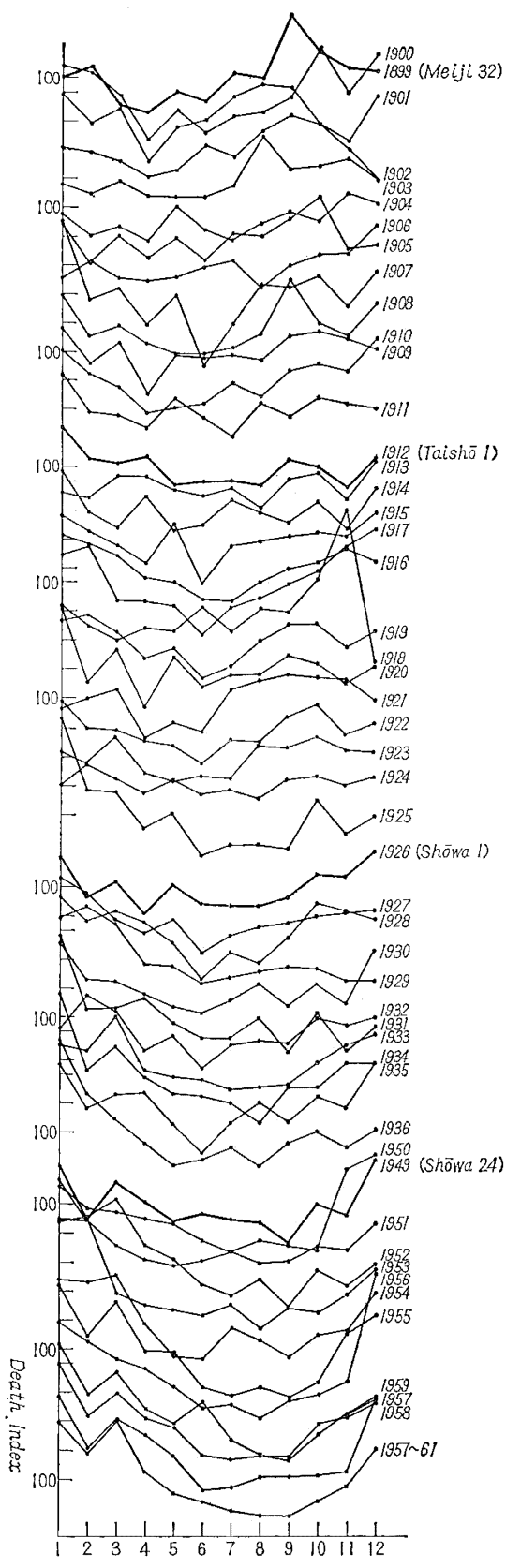

(b) Osaka

Fig. 11. The Death Index Curves of Heart Disease by Year. 


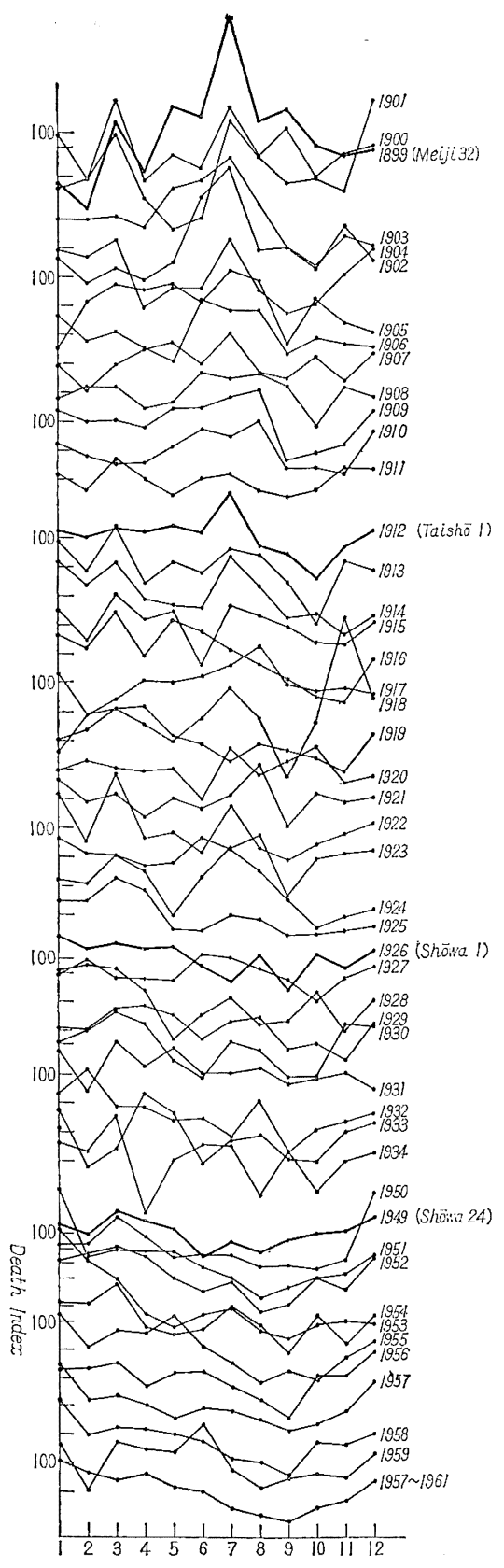

(c) Hokkaido



(d) Kagoshima 
food for some time, but they are now allowed to take suitable food as well as proper doses of antibiotics. These and many other circumstances may be considered as contributing to the gradual contraction of mortality in the hot months and transferring to the cold season some of the deaths which otherwise would happen in summer. Thus the transferred deaths plus the winter mortality which is as high as ever may naturally be regarded as forming a relatively high peak in the cold months.

This interpretation may also be applicable to apoplexy. In the first decades of this century, mortality was very high for this senile ailment. But deaths diagnosed as coming from it in those years might well be considered as involving cases actually caused by infectious diseases which now can easily be cured by antibiotics.

It is also to be noted that the frequency of deaths from apoplexy is synchronized with the violence of meteorological turbulences (fronts, typhoons, etc.) in September. In July and August, meteorological conditions are so constant and stable that even the sick can endure them, though it is hotter than in September. But violent changes in the meteorological environments may often turn out lethal to serious cases. Moreover, apoplexy is regarded as one of the typical autumn diseases, toge ther with such ailments as asthma, rheumatism and heart muscle stoppage. It is natural that mortality used to increase in this month of the year when medical techniques and services were in an undeveloped stage.

A complex of these and many other conditions, social and natural, may explain, though not at all completely, the steady decline of deaths in the hot months and the relative increase of mortality in the cold months. The question is: What measures should be taken to counteract the winter mortality peak of apoplexy? Incidentally, the gradual rising of the death curve for this disease in recent years results from the numerical gain of old people in the structure of population and from the senile nature of apoplexy.

\section{Retardation in decline of mortality}

Another notable phenomenon is the sign of the retardation in the decline of mortality for some diseases. After the war, the death rate rapidly shrank for various maladies, but its downward tempo has begun to mark time or taper off in some cases (for instance, tuberculosis, gastritis-enteritis group and pneumania-bronchitis, etc.)

In the case of tuberculosis, mortality sharply came down to 60-70 (per 100,000 of population) every month during 1951-52, but it has since been marking time. In 1963 , the rate came to 30 in winter, or the highest mark, 25 in spring, 20 in winter and 23 in autumn. (Fig. 12a.)

As for pneumonia-bronchitis, mortality showed a steep fall in 1948, but it has since been following a crab-like course. In 1963, it stood at 50-60 in winter, much higher than in other seasons (30-40 in spring, 20-30 in summer and 20-30 in fall). (Fig. 12b.)

Gastritis-enteritis group began to register a sharp downward tendency around 1945. Mortality in 1963 was again the highest in winter (20-25 as compared with $17-18$ in spring, $15-16$ in summer and $14-15$ in autumn). (Fig. 12c.) 


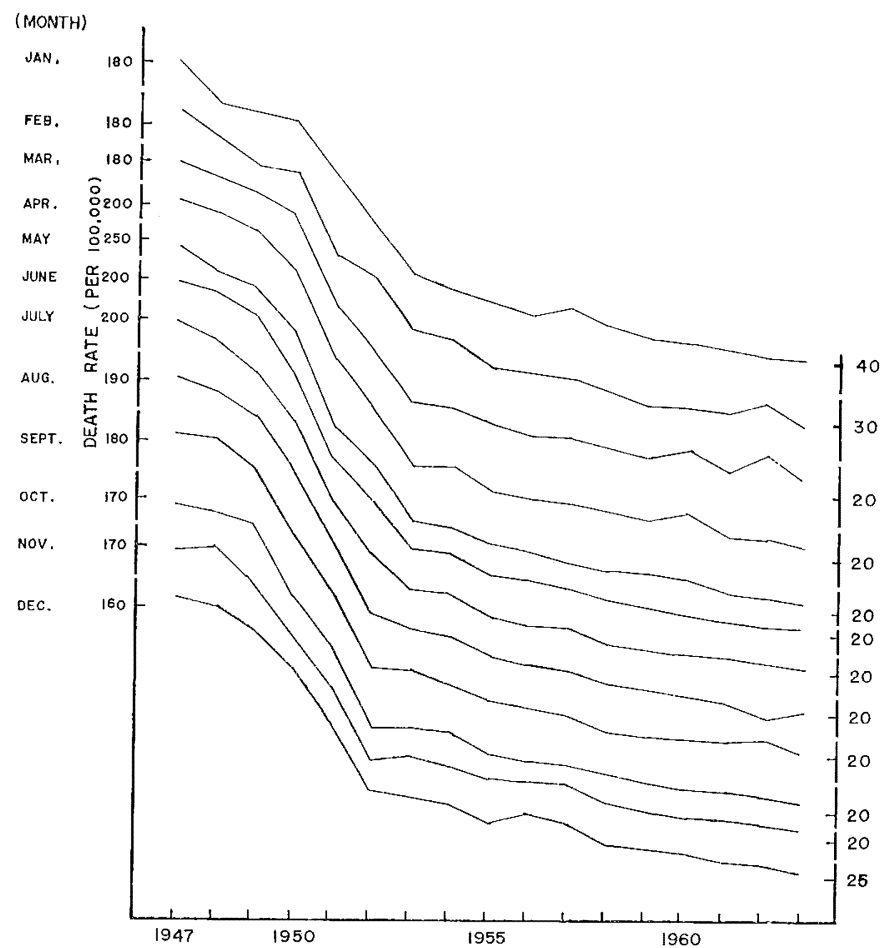

(a) Tuberculosis (Japan)

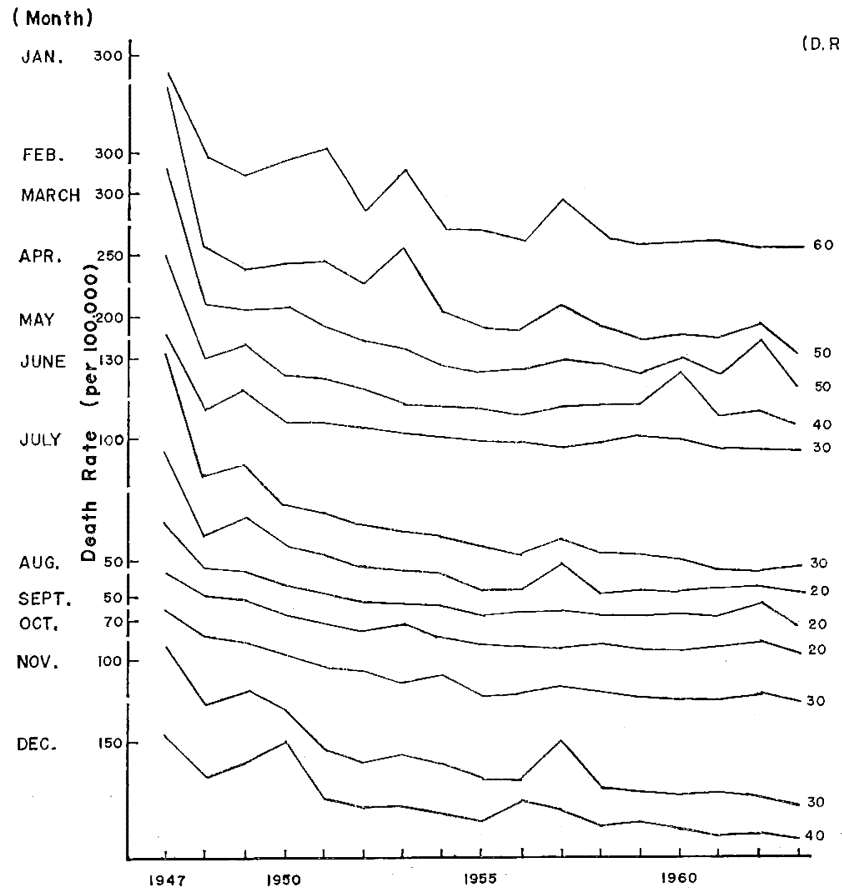

(b) Pneumonia and Bronchitis (Japan) 


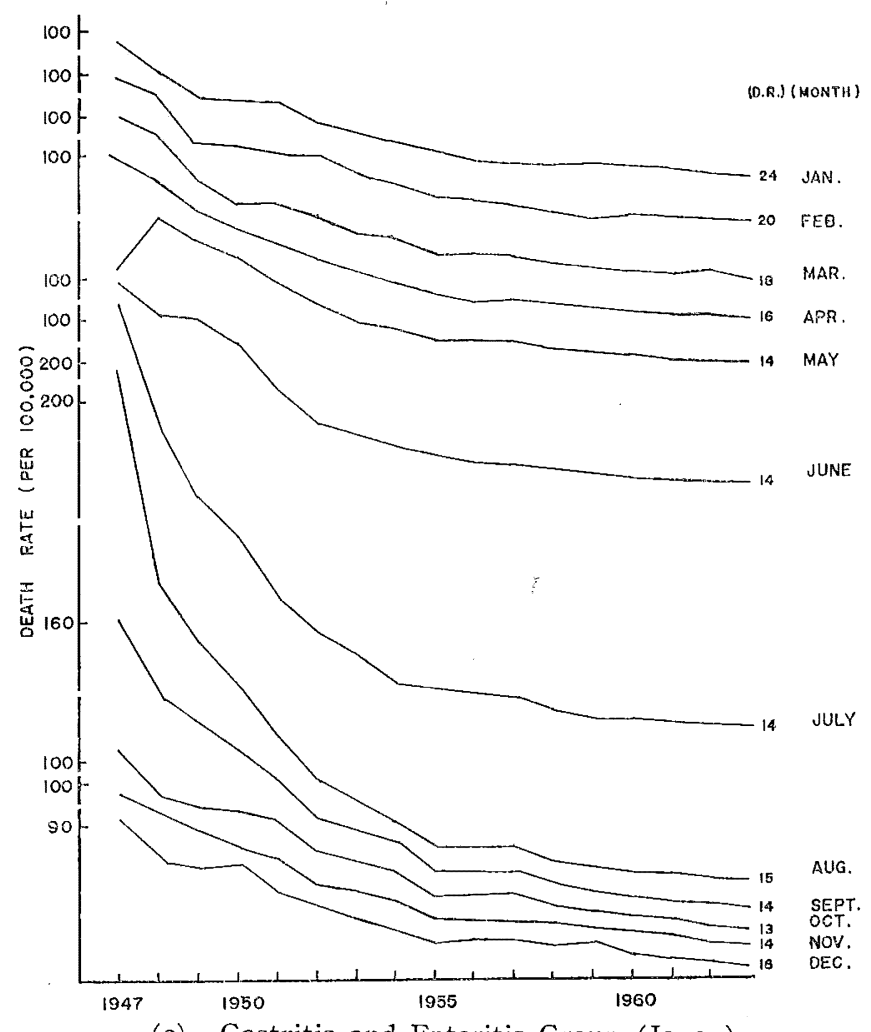

(c) Gastritis and Enteritis Group (Japan)

Fig. 12. Sign of retardation in Declinc of mortality.

For these three diseases, the slowing-up of the downward tempo is clearly seen in recent years and, moreover, the decrease has been much smaller in winter than in other seasons. It has been the biggest in summer in most cases.

Responsible for such retardation of the mortality contraction is, among others, the recent increase of drug-resistant bacteria. As other factors may be mentioned the increase of viruses, the recent changes in food and drink, and the ever accelerated progress of urbanization.

Signs of retardation of the mortality decline can be seen in the death index curves by year. Index figures are calculated month by month with 1950 as 100 . In the case of senile diseases (apoplexy and heart disease in particular), mortality has actually been on the upcurve.

As for apoplexy, the mortality index (with 1950 as 100) rose to 140 from January through May, 1962, though it remained almost on the same level in August. The index curve of heart disease was very similar to that of apoplexy in that the monthly index reached 1960 in February and March, with the summer and autumn positions remaining on the same mark. In both cases, the rising curve has been sharper in winter in contrast to the stagnant tendency in the hot season. (Fig. 13a, b.) 


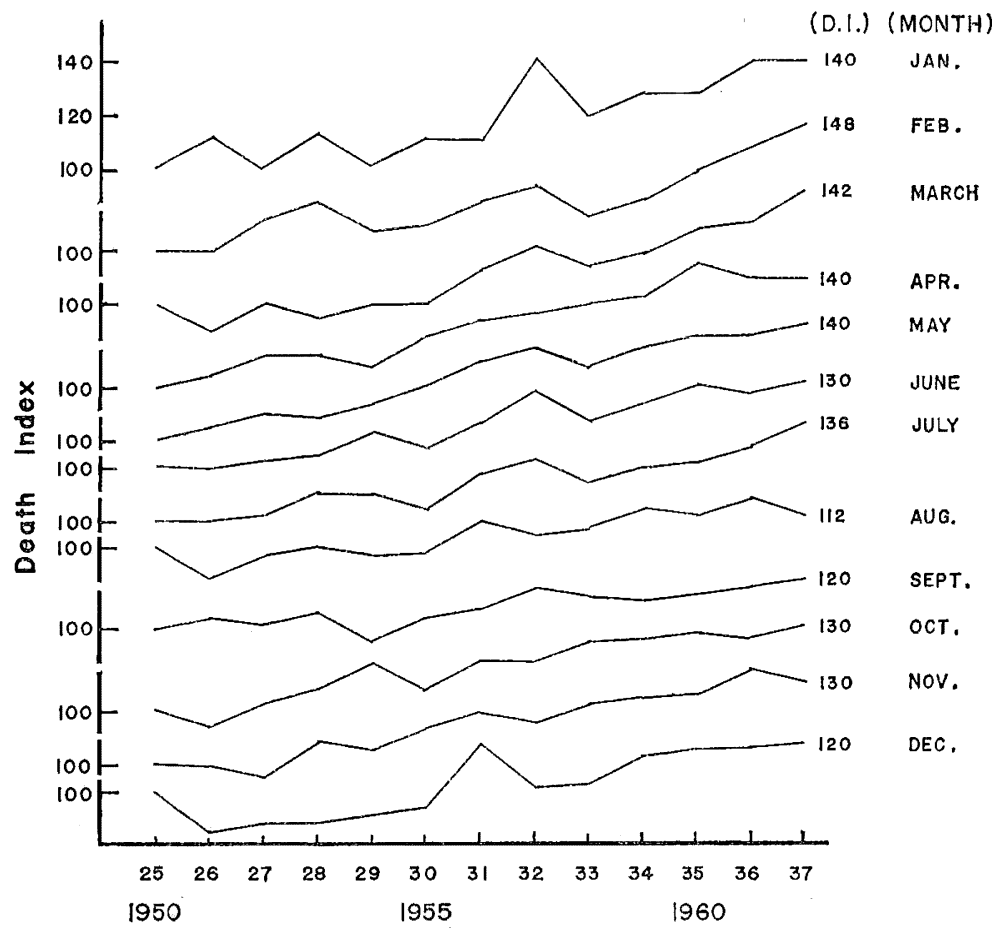

(a) Apoplexy (Japan)

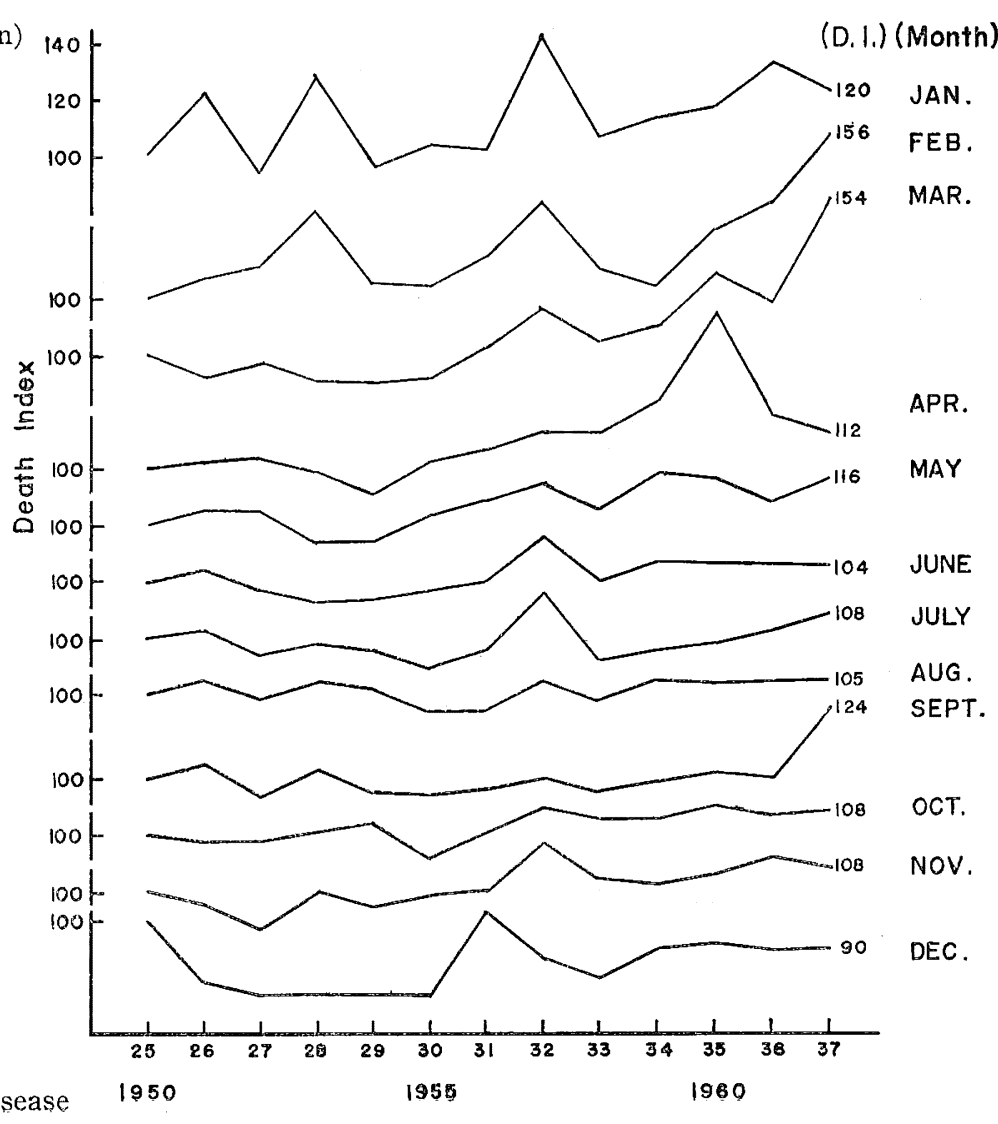

(D. I.) (Month)

Fig. 13. Sign of increase of mortality. 


\title{
References
}

M. Momíama (Sáamoto), 1960: The geographical study of seasonal diseases (I), Journ. Met. Soc. Japan, 38 , No. 1.

, 1961: The geographical study of seasonal diseases (II), ibid., 39.

, 1961: High winter mortality of "seasonal diseases," Papers in Met. and Geophy. Japan, 12, No. 2.

, Н. КІто, 1963; A Geographical study of seasonal disease calendar models by period and country, ibid., 14, No. 2.

, 1963: A Study in the Seasonal Disease Calendars by Age, ibid , 14, Nos. 3-4.

\section{季節病リズムの変遷に関する研究}

\author{
粐山政子
}

疾病及び死亡の季節変化の㥞相は, 昔から現代に至るまで,ささざまな変遷をとげてきている。昔は比 較的，気候の影響をとのまま区胦して，これらの季節的分布が決定されていたが，人間社会の進歩ととも 飞，季節的分布の棣相梳大きく変ってきた。


しかも, 冬の赤淑患者の発生割合は, 年々增加しているが, 夏の患者発生割合は, むしろ減少していると いった具合である。

また，死亡率の季節変動の型式も，時代的飞著しい移り変りをみせている。

死亡率の季節变動型式の移り変りから，“移行型”之“逆転型”の二つと分類できる。

移行型：がんがこれと入る。がんは明治，大正の頃には8月を中心夏の山があったが，それが火゙れだ 儿移行して最近では 10 月を中心秋の山がある。季節变動倸数は 0.1 位から 0.04 と最近では半分にちお゙ まって，季節変動が縮少してきた事を示す。

逆転型：逆転型 “A” は昔は夏飞山があったが，現在では山が消えて谷となり，冬の部分の低下がそれ ほど著明でないため, むしろ冬がクローズアップされて逆転したタイプである。腸炎, 脚気, 結核などが ある。

逆転型：“B” 㟙は夏と冬の 2 つの山があり，それが夏山の低下により完全飞冬だけ一つ山を持つ型 飞変型した。成人病としての脳卒中, 心臟病, 老衰がこれである。

つぎそ; 季節变動型式の時代的变化がなぜ呿こったが考えてみる。たとえば, 脳卒中や心臟病の場合， 発病の問題恃ともかくとして, 昔は夏の暑い時期飞, 暑さの影響をとのまま受けて患者の体力は消耗し,


る。それが医療技術の進歩，新薬の発見などで，夏に死奴等の患者の生命を延長でき，冬にまで持ち越さ れた結果ではないかと考兄られる。

一方, 疾病死亡の季節変化の変遷と必ずしも対応するわけではないが, 人体機能の季節変化飞も変遷が 呿きているようである。即ち人体の基礎代謝の四季汭たる变動カーブ, 人体の血球比重の季節变動カー ブは，何れも最近では季節变化が縮少してきている。

また, 最近, あらたと登場してきた問題として “死亡率低下の停滞現象”がある。戦後さまざまな疾病 死亡率が低下したが，ある時点からは横ばい状態飞なっている。肺炎，腸炎，結核等の細菌性疾患は，ぞ の季節飞括いても停滞現象飞近い傾向がみられる。

これとは逆に，脳卒中，心臟病などの成人病は，年令層の老令化にともなって，最近はとの死亡率はま すます高まる傾向炕ある。季節的《は冬季堵しい。 